\title{
Legal Protection of Cultural Objects in the Armed Conflict
}

\author{
Akbar Kurnia Putra*; Bernard Sipahutar ${ }^{\star \star}$; Vrandza \\ Iswenanda ${ }^{\star \star \star}$; Sulhi Muhammad Daud ${ }^{\star \star \star \star}$ \\ Faculty of Law, Universitas Jambi \\ ^akbarkurnia@unja.ac.id

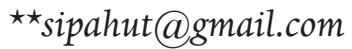 \\ $\star \star \star$ vrandza@outlook.com \\ $\star \star \star \star s u l h i d a u d @ g m a i l . c o m$
}

\begin{abstract}
This article aims to overview how the International Humanitarian Law regulates the protection of cultural heritages at the event of armed conflict. Applying a normative legal method, this article coclude that the protection for the cultural objects during an armed conflict is regulated in the Hague Convention IV of 1907, the Geneva Conventions IV of 1949, the Hague Convention of 1954, and the Second Protocols to the Hague Convention of 1954 for the Protection of Cultural Property in the Event of Armed Conflict 1999. The Hague Convention of 1954 mentions about safeguarding of the cultural property from any harm as a result of armed conflicts and about respect for the cultural objects. Each nation is responsible to avoid, prevent, and forbid any harfmul acts against cultural property. However, no stipulation is mentioned on how the victims whose cultural objects are destroyed could sue for any destructions. Therefore it is recommended that a special International Body be formed to supervise any harmful activities toward the cultural objects. Such a body might be more than just an International Court of Justice whose function is to settle any objections, sues, or claims from parties whose cultural objecs have been destroyed during armed conflicts.
\end{abstract}


Keywords: Cultural objects; Armed Conflict; International Humanitarian Law.

\section{A. Introduction}

Armed conflict brings about negative impact and great loss to humanity, both for combatants who actually or actively engage in the conflict and for civilians who do not directly engage in the conflict. Armed conflict not only affects individuals, but also property or cultural property that has its own economic and historical value.

The International Humanitarian Law strongly regulates the behavior of a military operation by taking into consideration the humanitarian value ${ }^{1}$. Military attacks in an armed conflict should be limited only to military targets and not to civilian objects or sites even though the shapes, location, purpose and usage, the damage, and the mastery or neutralization of these objects or sites will, under the prevailing conditions, provide a real military benefits. ${ }^{2}$

Parties involved in an armed conflict are prohibited from taking any hostile actions aimed at historical monuments, works of art, or places of worship which are cultural or spiritual heritage of a nation and use these objects to support military efforts. ${ }^{3}$ Nevertheless, in the application of the rules of international humanitarian law, it is often found that objects or historic properties are used as military targets. This causes damage or destruction to property or cultural objects because destruction is an inevitable component of war. ${ }^{4}$ Damaging and destroying buildings and looting valuable objects belonging to an opponent during times of armed conflict is one way to gain psychological benefits and obtain wealth, while the other goal is a sign

1 Malcolm N. Shaw, Hukum Internasionl, Nusa Media, Bandung, 2013, p.1194.

2 Delegasi Regional ICRC, Hukum Humaniter Internasional, ICRC, Jakarta, 2015, p.51.

3 Article 53 Additional Protocol I of 1977 for the IV Geneva Convention of 1949.

4 Hirad Abtahi, "The Protection of Cultural Property in Times of Armed Conflict: The Practice of the International Criminal Tribunal for the Former Yugoslavia," Harvard Human Rights Journal, Spring 2001, p. 1. 
of conquest of the enemy.

Cultural objects as a world heritage assumes the history of human development and has a high historical value. They serve as source of information on science that bring messages from generation to generation, therefore, are important for the existence of human beings. The disappearance of cultural objects and historic sites destroys the traces of civilization and uniqueness to uncover the chain of history of human life.

The real form of legal protection provided by international law can be seen by the establishment of the Hague Convention for the Protection of Cultural Property in the Event of Armed Conflict in 1954, which is the first international agreement that comprehensively regulates the legal protection over cultural objects during armed conflict. The Hague Convention of 1954 exclusively reserved The High Contracting Party to prepare in peacetime for the safeguarding of cultural property situated in their own territory against the foreseeable effects of an armed conflict, by taking such measures as they consider appropriate. ${ }^{5}$

The aforementioned of three instruments of international agreement respond to four forms of threats to cultural objects in times of an armed conflict, namely attacks on intentional cultural objects, accidental damage to cultural objects, looting of cultural objects, and theft of cultural objects. ${ }^{6}$ However, given the nature of the international agreement that only applies to contracting party, there are various international customs serve as a source of international law to fill the gaps contained in international agreements. ${ }^{7}$ Violation against the protection of cultural objects during armed conflict has become one of the problems that should have been resolved by the instruments of International Humanitarian Law in order to achieve a legal certainty in the protection of these cultural objects.

5 Article 3 of the hague Convention of 1954.

6 Ibid.

7 Mochtar Kusumaatmadja and Etty R. Agoes. Pengantar Hukum Internasional, P.T Alumni, Bandung, 2003, p. 143. 


\section{B. Defination of Cultural Objects}

Culture in Indonesian language is budaya. Some argues that the word budaya is originated from Sanskrit buddhayah, a plural form of buddhi (conscious). It is something related to mind (or in Indonesian language is budi) and reasoning. Some other mentions that budaya derives from words budi and daya. Budi refers to spiritual element of a man and daya refers to physical power of human. Hence, budaya means the result of spiritual and physical power of human. ${ }^{8}$ Koentjaraningrat argues that culture is divided or classified into three forms, namely: ${ }^{9}$

1. Culture is a complex of ideas, ideas, values, norms, and regulations. This shows that culture is abstract, cannot be touched, held or photographed, and it rests in the minds of the citizens of the community where the culture in question lives. This ideal culture is also called the code of conduct. Ideal culture has the function of regulating, controlling, and giving direction to the actions, behavior and actions of people in society as courtesy. It can be called customs or customs, which are now widely stored in archives, tapes, and computers. In conclusion, ideal culture is an embodiment and culture that is abstract;

2. Culture is a complex of activities and patterned actions from human beings in society. This form is called the social system, because it involves the actions and behavior patterned from human themselves. This form of culture can be observed, photographed, and documented because in this social system there are human activities that interact and relate and interact with one another in society. More visible in the form of behavior and language when they interact in the association of daily life in society. In conclusion, this social system is a concrete manifestation of culture, in the form of behavior and language;

3. Culture is a concrete human creation. This is called physical culture. This cultural form is almost entirely a physical result (the actions and the work of all humans in society). It is mostly tangible in the form of objects or things that can be touched, seen, and photographed, large or small. For example: Borobudur Temple (large), batik cloth, and shirt buttons (small), building techniques, for example, how to make walls with different house foundations depending on conditions. In conclusion, this physical culture is a concrete manifestation of cul-

8 Herimanto, Imu Sosial \& Budaya Dasar, Bumi Aksara, Jakarta, 2011, p 24.

9 Elly M. Setiadi et al, Ilmu Sosial Budaya Dasar, PT. Kencana, Jakarta, 2006, p. 27. 
ture, in the form of material/artifacts. ${ }^{10}$

According to John Henry Merryman: "Cultural objects or cultural wealth are objects that have artistic, ethnographic, archaeological or historical values." ${ }^{11}$ Cultural objects are also defined in various international agreements regarding cultural objects. The Convention for the Protection of Cultural Property during Armed Conflict in 1954 or also called the Hague Convention 1954 defines cultural objects as:

a) Movable or immovable property of great importance to the cultural heritage of every people, such as monuments of architecture, art or history, whether religious or secular; archaeological sites; groups of buildings which, as a whole, are of historical or artistic interest; works of art; manuscripts, books and other objects of artistic, historical or archaeological interest; as well as scientific collections and important collections of books or archives or of reproductions of the property defined above;

b) Buildings whose main and effective purpose is to preserve or exhibit the movable cultural property defined in sub-paragraph (a) such as museums, large libraries and depositories of archives, and refuges intended to shelter, in the event of armed conflict, the movable cultural property defined in sub-paragraph (a);

c) Centers containing a large amount of cultural property as defined in sub- paragraphs (a) and (b), to be known as centers containing monuments." 12

Another international convention that provides an understanding of cultural objects is the Convention on the Means of Prohibiting and Preventing the Illicit Import, Export, and Transfer of Ownership of Cultural Property 1970. In this convention, cultural property or cultural property is defined as follows: ${ }^{13}$

"For the purposes of this Convention, the term "cultural property" means property which, on religious or secular grounds, is specifically

10 The translation is provided by the author.

11 UNESCO, UNESCO'S Response to Protect Culture In Crises, Unite4heritage, 2016 , p. 5.

12 Article 1 of the Hague Convention on te Protection of Cultural Objects during Armed Conflict..

13 Article 1 of the convention on the means of Prohibiting and Preventing the Illicit Import, Export and Transfer of Ownership of Cultural Property of 1970 
or designated by each State as being of importance for archaeology, prehistory, history, literature, art of science, and which belongs to the following categories:

(a) Rare collections and specimens of fauna, flora, minerals and anatomy, and object of paleontological interest;

(b) property relating to history, including the history of science and technology, and military and social history, to the life of national leaders, thinkers, scientists and artists and to the event of national importance;

(c) products of archaeological excavations (including regular and clandestine) or of archaeological discoveries;

(d) elements of artistic or historical monuments or archaeological sites which have been dismembered;

(e) antiquities more than one hundred years old, such as inscriptions, coins and engraved seals;

(f) objects of ethnological interest;

(g) property of artistic interest, such as:

(i) pictures, paintings and drawing produced entirely by hand on any support and in any material (excluding industrial designs and manufactured articles decorated by hand);

(ii) original works of statuary art and sculpture in any materials

(iii) original engravings, prints and lithographs;

(iv) original artistic assemblages and montages in any material;

(h) rare manuscripts and incunabula, old books, documents and publications of special interest (historical, artistic, scientific, literary, etc.) singly or in collections;

(i) postage, revenue, and similar stamps, singly or in collections;

(j) archives, including sound, photographic and cinematographic archives;

(k) articles of furniture more than one hundred years old and old musical instrument."

With the definition obtained from this convention, it is understood that cultural objects require the designation or endorsement by the state as cultural objects in religious and secular treasures considered important in archeology, prehistory, history, literature, art and science. In addition, examples of cultural objects are also mentioned 
in accordance with the categorization of cultural objects as regulated in this convention.

The Convention on the Means of Prohibiting and Preventing the Illicit Import, Export, and Transfer of Ownership of Cultural Property of 1970s were international conventions aimed at protecting cultural property by overseeing trade, also bridging inter-governmental cooperation to search for and rediscover cultural objects that had already been illegally stolen or taken across national borders. This convention outlines the importance of cultural objects because they are one of the basic elements of civilization in national culture, and these values should be guarded as much as possible regarding their origins, history and traditional arrangements.

Article 1 of the UNESCO's World Heritage Convention of 1972 on Protection of the World Cultural and Natural Heritage defines cultural heritage as:

1. Monuments: architectural works, works of monumental sculpture and painting, elements or structures of an archeological nature, inscriptions, cave dwelling and combination of features, which are of outstanding universal value from the point of view of history, art or science;

2. Groups of buildings: groups of separate or connected buildings which, because of their architecture, their homogeneity or their place in the landscape, are of outstanding universal value from the point of view of history, art or science;

3. Sites: works of man or the combined works of nature and man, and areas including archeological sites which re of outstanding universal value from the historical, aesthetic, ethnological or anthropological point of view.

Based on the description above, it can be concluded that cultural object in general sense has a broad and different meanings and is defined in various terminologies such as cultural property, cultural or natural heritage. Nonetheless, cultural objects as a manifestation of culture with developmental influence to a civilization from various generations must be protected and preserved. 


\section{Overview of Armed Conflict}

International humanitarian Law is a guideline to overcome problems that may arise from the occurrence of armed conflict; however, there is no single definition of armed conflict mentioned in the law. On the other hand, The Commentary on the Geneva Conventions of 1949 included the term in articles related to armed conflict, as the following:

"Any different arising between two states and leading to intervention of armed forces is an "armed conflict" within the meaning of Art.2, even if are of the parties denies the existence of a state of war. It makes no difference how long the conflict lasts, or how much slaughter takes place." 14

It is learned that armed conflict is any situation where a conflict of interest between other countries or a conflict between groups that are in one area of the country lead to the intervention of the armed forces, even though there is no acknowledgment or denial from a party about the existence of the conflict, how long the conflict lasts, and how many disputes occur. An armed conflict, the parties to the conflict are not limited to conflicts between countries, thus providing a broad definition of the armed conflict itself.

Armed conflict can be divided into two parts, namely international and non international armed conflict. The difference between the two parts lies on the characteristics of the conflict: whether or not the conflict is of an international character. ${ }^{15}$ International armed conflict involves a war between two or more countries; meanwhile, non international armed conflict involves offensives against non state armed groups by a sovereign nation. ${ }^{16}$

14 Jean S. Pictet, "Commentary on the Geneva Conventions of 12 August Volume IV: Geneva Convention relative to the Protection of Civilian Persons in Time of War," International Committee of the Red Cross, 1999, p. 32.

15 Malcolm N.Shaw, Op. Cit., p. 1197.

16 Ambarwati, Denny Ramdhany, Rina Rusman, Hukum Humaniter Internasional dalam Studi Hubungan Internasional, RajaGrafindo Persada, Jakarta, 2010. p.53 


\section{International Armed Conflict}

As stated in the concurrent provisions of Article 2 of the $1949 \mathrm{Ge}$ neva Convention, international armed conflict is an armed dispute involving two or more countries, both as an announced armed conflict and if the statement of armed conflict is not recognized by one of them. ${ }^{17}$

a. A Pure International Armed Conflict

A pure international armed conflict is an armed conflict that occurs between two or more countries. In this armed conflict all major humanitarian law conventions apply, namely the Hague Convention of 1907, the Geneva Conventions of 1949, and Additional Protocol I of 1977. Other agreements or conventions governing humanitarian law will also apply if the parties to the war have ratified. ${ }^{18}$

b. A Pseudo-International Armed Conflict

A pseudo-international armed conflict is an armed conflict between states, on one end, and non-state entities, on the other end. This kind of conflict should not belong to the category of armed conflict that is not international in nature, but based on the provisions of Humanitarian Law in Article 1 (4) of Additional Protocol I of 1977, this armed conflict is equated with international armed conflict. Pseudo-international armed conflict is then divided into two parts, namely:

1) National Liberation War

Provisions regarding the wars of National Liberation can be found in Article 1 (4) of Additional Protocol I of 1977. This article must be linked to Article 96 (3) of Additional Protocol I of 1977 which regulates the procedure of how the Geneva Conventions or Additional Protocol I of 1977 can be applied to this armed conflict. ${ }^{19}$ According to the convention, the regulations can be applied if a) the authority and the people of the contracting party declare a unilateral statement of conflict, b) submit the statement to the

17 Ibid., p.56

18 Haryomataram, Konflik Bersenjata dan Hukumnya, Universitas Trisakti, Jakarta, 2002, p. 11.

19 Ibid. 
depository, that is the Swiss Federal Council, and c) is willing to obey the Convention and the Protocol. ${ }^{20}$

2) Internationalized Internal Armed Conflict

Internationalized internal armed conflict occurs if a) a nation acknowledges a rebellious conduct of a certain group of people as belligerent, b) one or two other nations offer their helps by mobilizing their army to one side of the contracting parties, and c) each side of the contracting parties receive military supports from third party. Nevertheless, neither the Geneva Convention or the Protocol provide a clear regulation for this kind of conflict. ${ }^{21}$

\section{Non International Armed Conflict}

Article 3 of the Geneva Conventions of 1949 determines the rules of International Humanitarian Law and the obligations of the parties to protect the victims arose from a non international armed conflict. Nevertheless, the article does not provide the criteria or definition of non international armed conflict. ${ }^{22}$ Commentary of Geneva Convention interprets a non-international armed conflict as follows:

a. Those who rebel against the de jure government have an organized military force, under responsible commanders, acting in certain territories and guaranteeing the honor of this convention;

b. That the legitimate government is forced to mobilize regular military force to deal with militarily organized rebels who control part of the national territory;

c. (3) that the de jure government has recognized the rebels as belligerent or the government admits themselves as belligerent or the government admits that the rebel group as belligerent for the purpose of Convention or the Security Council or the General Assembly has classified the rebellious conduct as a violation against global peace or as an act of aggression;

d. That the rebel group possesses a state-like organization.

20 Ibid., p.12.

21 Ibid., p. 13

22 Ambarwati, Denny Ramdhany, Rina Rusman, Op.Cit., p.59 


\section{International Humanitarian Legal Provisions}

International Humanitarian Law is the first international law to give protection to cultural objects. The embodiment of the law is proven by the establishment of the Hague Convention II o 1899 and the Hague Convention IV of 1907. The two conventions are the first international agreements containing legally binding regulations in the protection of cultural objects. In the following, other legal entities regarding protection over cultural property are produced. For example, the Geneva Convention IV Relative to the Protection of Civilian Persons in Times of War is published in 1949, the Hague Convention for the Protection of Cultural Property in the Events of Armed Conflict is issued in 1954, the Protocols to the Geneva Conventions of 12 August 1949 is formulated in 1949, and the Protocols to the Hague Convention of 1954 for the Protection of Cultural Property in the Event of Armed Conflict is produced in 1999. In addition, the protection of cultural objects during armed conflict is also regulated in international custom law. This law requires every nation in the world to be bound by international customary law in terms of protection of cultural property during armed conflict even though they are not bound by an international agreement.

Section II, Article 23 (g) of the Hague Convention IV of 1907 mentions about the prohibition to destroy or seize the enemy's property, unless such destruction or seizure be imperatively demanded by the necessities of war. In Article 27 of the convention, stipulated that:

In sieges and bombardments all necessary steps must be taken to spare, as far as possible, buildings dedicated to religion, art, science, or charitable purposes, historic monuments, hospitals, and places where the sick and wounded are collected, provided they are not being used at the time for military purposes. It is the duty of the besieged to indicate the presence of such buildings or places by distinctive and visible signs, which shall be notified to the enemy beforehand.

These articles clearly obliged all parties involved in war not to utilized any protected property belonged to the enemy. Should the property be used for military purposes, the provision of the protec- 
tion provided in Article 23 and 27 can be excluded and the act of destruction of the protected property, hence, be justified. Additionally, the second paragraph states that the threatened party should indicate their protected properties to the enemy and protect them from any harm which might arose from conflict. Prohibition to destroy cultural objects can also be found in Article 56 of the Hague Convention IV of 1907. It is written that:

The property of municipalities, that of institutions dedicated to religion, charity and education, the arts and sciences, even when State property, shall be treated as private property. All seizure of, destruction or wilful damage done to institutions (dedicated to religion, charity and education, the arts and sciences), historic monuments, works of art and science, is forbidden, and should be made the subject of legal proceedings.

The development of International Humanitarian Law allows the establishment of other international treaties such as the Geneva Conventions of 1949. The Geneva Conventions of 1949 consists of four parts and 47 articles. ${ }^{23}$ On contrary to the Hague Convention of which regulating the tools and methods of war, the Geneva Conventions governs the protection over the victims of war. ${ }^{24}$ Having reviewed the Conventions IV Relative to the Protection of Civilian Persons in Time of War of 1949, the authors found two articles are in relevant to the discussion of the protection of cultural objects, namely Article 27 and 53.

Article 27 of the convention stated "protected persons are entitled, in all circumstances, to respect for their persons, their honour, their family rights, their religious convictions and practices, and their manners and customs." Even though there is no direct statement about the protection of cultural object in this article, it might be used as a reference to protect cultural objects containing religious and cultural values. ${ }^{25}$ Article 53 of the convention stipulated:

23 Haryomataram, Hukum Humaniter, RajaGrafindo Persada, Jakarta, 2005, p. 6.

24 Ibid, p. 49.

25 Patrick J. Boylan, "Review of the Convetion for the Protection of Cultural Property in the Event of Armed Conflict (The Hague Convention of 1954)," UNESCO Doc, 1993, p. 38. 
Any destruction by the Occupying Power of real or personal property belonging individually or collectively to private persons, or to the State, or to other public authorities, or to social or cooperative organizations, is prohibited, except where such destruction is rendered absolutely necessary by military operations

This article differentiates civilian object from that of the military. The article forbids the contracting parties from attacking and destroying non combatant population and civilian objects, ${ }^{26}$ unless such destruction is the necessity of the military purpose. ${ }^{27}$

These articles reinforce the previous regulations, ywt does not provide a definite regulation on the protection of cultural war during armed conflict. Thus, in 1954, based on the recommendation from UNESCO (United Nations Education, Science, and Cultural Organization), the Hague Convention for the Protection of Cultural Property in the Event of Armed Conflict was published. This convention exclusively designed to regulate the protection over cultural object during armed conflict. ${ }^{28}$

As a single legal entity, the Convention for the Protection of Cultural Property in the Event of Armed Conflict of 1954, contributes to major changes in the protection of cultural property and substitutes the previous regulations which, with the advancement of weaponry and fighting methods, are inadequate to keep cultural objects from damage and destruction. This convention governs the protection of cultural property during international and non international armed conflict. It also contains legislation on safeguarding the cultural objects in peacetime. For provisions of the convention, an official declaration of war or recognition that a conflict is an armed conflict is not needed. A clear hostile action is sufficient to enforce the rules of this

26 Patrick J. Boylan, "Review of the Convetion for the Protection of Cultural Property in the Event of Armed Conflict (The Hague Convention of 1954)," Op. Cit., p. 38.

27 Jean S. Pictet, "Commentary on the Geneva Conventions of 12 August Volume IV: Geneva Convention relative to the Protection of Civilian Persons in Time of War," International Committee of the Red Cross, 1999, p. 301.

28 Irina Bokova, Introduction to Basic Texts for the 1954 Hague Convention for the Protection of Cultural Property in the Event of Armed Conflict and it's two (1954 and 1999) Protocols, UNESCO, 2010, p. 5. 
convention. ${ }^{29}$ Apart from the provisions that apply in peacetime, this convention applies to any declared war or any armed dispute that may arise between two or more parties bound to this convention, even if the conditions of war are not recognized by one or more of those involved in warfare. ${ }^{30}$

If one of the parties in conflict is not a Party to this convention, the parties which are part of this convention must be bound by the convention, and in their mutual relations. ${ }^{31}$ The regulations mentioned in the Hague Convention of 1954 are also applied to non parties of the convention if they declared to accept the provisions. ${ }^{32}$ In general, the Hague Convention of 1954 divides the protection in two aspects of safeguarding of and respect for cultural property. ${ }^{33}$ Safeguarding refers to any necessary action taken to make sure the safety of cultural objects in times of armed conflict, and respect for the cultural property means the obligation of the High Contracting Parties to avoid, prevent, and forbid hostile conduct against protected cultural objects. Article 3 of the Hague Convention of 1954 mentioned "the High Contracting Parties undertake to prepare in time of peace for the safeguarding of cultural property situated within their own territory against the foreseeable effects of an armed conflict, by taking such measures as they consider appropriate." Furthermore, Article 4 stated the provisions of respect for cultural property as follow:

1. The High Contracting Parties undertake to respect cultural property situated within their own territory as well as within the territory of other High Contracting Parties by refraining from any use of the property and its immediate surroundings or of the appliances in use for its protection for purposes which are likely to expose it to destruction or damage in the event of armed conflict; and by refraining from any act of hostility, directed against such property;

2. The obligations mentioned in paragraph 1 of the present Article may

29 Ibid., p. 196.

30 Article 18 (1) The Hague Convention of 1954 on the Protection of Cultural Property in Time of Armed Conflict.

31 Ibid., Article 18 (3).

32 Ibid.

33 Ibid., Article 2 
be waived only in cases where military necessity imperatively requires such a waiver;

3. The High Contracting Parties further undertake to prohibit, prevent and, if necessary, put a stop to any form of theft, pillage or misappropriation of, and any acts of vandalism directed against, cultural property. They shall refrain from requisitioning movable cultural property situated in the territory of another High Contracting Party;

4. They shall refrain from any act directed by way of reprisals against cultural property;

5. No High Contracting Party may evade the obligations incumbent upon it under the present Article, in respect of another High Contracting Party, by reason of the fact that the latter has not applied the measures of safeguard referred to in Article 3.

The Second Protocols to the Hague Convention of 1954 for the Protection of Cultural Property in the Event of Armed Conflict 1999 coined a special protection over the cultural property as enhanced protection. This protects not only immovable objects such as cultural buildings, monuments, or art pieces but also archives, libraries, museums, and other moveable objects. ${ }^{34}$

Enhanced protection is granted for cultural heritage of the greatest importance for humanity, it is protected by adequate domestic legal and administrative measures that recognizes its exceptional cultural and historic value, and is not used for military purposes or to shield military sites. ${ }^{35}$ Each Party is responsible to make a list of protected cultural properties and submit a request to the Committee for the protection of cultural property during an armed conflict. Once the property is listed on List of Cultural Property under Enhanced Protection, the protection of the property has been enhanced. ${ }^{36}$

34 Jiri Toman, Cultural Property in War: Improvement in Protection, UNESCO Publishing, Paris, 2009, p. 190. Available at https://books.google.co.id/ books?hl=id\&lr $=\& \mathrm{id}=2 \mathrm{XpYCgAAQBAJ} \& \mathrm{oi}=\mathrm{fnd} \& \mathrm{pg}=\mathrm{PA} 5 \& \mathrm{dq}=\mathrm{jiri}$ + toman, +cultural+property+in+war:+improvement + in + protectio $\mathrm{n} \&$ ots $=\mathrm{x} 9 \mathrm{O} 5 \mathrm{EnIH} \_\& \mathrm{sig}=\mathrm{mj}$ FUVsrTlz5 NvCzUZlwXwqiUpc\&redir esc $=y \# v=$ onep $\& \mathrm{q}=$ jiri $\% 20$ toman $\% 2 \mathrm{C} \% 20$ cultural $\% 20$ property $\% 20$ in $\% 20 \mathrm{war} \% 3 \mathrm{~A} \% 20 \mathrm{improvement} \% 20 \mathrm{in} \% 20$ protection $\& \mathrm{f}=$ false.

35 Article 10 of the Second Protocols to the Hague Convention of 1954 for the Protection of Cultural Property in the Event of Armed Conflict 1999.

36 Article 11 of the Second Protocols to the Hague Convention of 1954 for the 
For the provisions of the protection for cultural objects in the event of armed conflict as stipulated in International Humanitarian Law be adhered to by all parties, any breach of the regulations shall be sanctioned. Article 28 of the Hague Convention of 1954 stated:

The High Contracting Parties undertake to take, within the framework of their ordinary criminal jurisdiction, all necessary steps to prosecute and impose penal or disciplinary sanctions upon those persons, of whatever nationality, who commit or order to be committed a breach of the present Convention.

Nevertheless, the granting of sanction as regulated in the present convention is considered weak and contributes less protection to cultural objects. For this reason, the Second Protocols to the Hague Convention of 1954 for the Protection of Cultural Property in the Event of Armed Conflict 1999 revises the regulation on sanction against hostile act on cultural objects. Based on the protocol, each country has two different obligations on the way they should sanction each violation. The first relates to serious offense against the protected cultural property, and the second concerns other violations.

Serious violation is defined in five levels, they are 1) a deliberate act of violation against protected cultural properties, 2) a deployment of protected cultural objects in military operation, 3) a destruction of protected cultural property, 4) an act of making the protected cultural property a target of attacks, and 5) an act of theft, looting, fraud, and vandalism against the protected cultural objects. ${ }^{37}$ The High Contracting Parties shall take necessary steps to define these serious violations as criminal actions based on the prevailing national laws, therefore punish the perpetrators with sanction they deemed appropriate..$^{38}$ In addition, Article 15 of the present protocol suggested the High Contracting Parties to adopt legislation, legal instruments, administrative sanctions or other steps to suppress the deliberate act of violation against protected cultural property such as all form of usage of protected cultural objects other than those previ-

Protection of Cultural Property in the Event of Armed Conflict 1999.

37 Article 15 of the Second Protocols to the Hague Convention of 1954 for the

Protection of Cultural Property in the Event of Armed Conflict 1999. 38 Ibid. 
ously mentioned in the Hague Convention of 1954 and the Second Protocols to the Hague Convention of 1954 for the Protection of Cultural Property in the Event of Armed Conflict 1999, illegal exports of the protected cultural objects, or illegal transfer of ownership of the cultural objects. While serious offense should be referred to as criminal conduct, other act of violation may or may not be considered as criminal act. It depends on the decision made each country.

\section{E. Conclusions}

The protection for the cultural objects during an armed conflict is regulated in the Hague Convention IV of 1907, the Geneva Conventions IV of 1949, the Hague Convention of 1954, and the Second Protocols to the Hague Convention of 1954 for the Protection of Cultural Property in the Event of Armed Conflict 1999. The Hague Convention of 1954 mentions about safeguarding of the cultural property from any harm that may arise from an armed conflict and also about respect for the cultural objects. Each nation is responsible to avoid, prevent, and forbid any harfmul act against cultural property. Despite the regulation on the protection for the cultural objects elsewhere in the International Humanitarian Law, no stipulation is mentioned on how the victims whose cultural objects are destroyed could go to sue for any destruction. This article recommend that a special International Body be formed not only to supervise any harmful activities toward the cultural objects based on the International Law. Such a body might be more than just an International Court of Justice whose function is to settle any objections, sues, or claims from parties whose cultural objecs have been destroyed during armed conflicts.

\section{Bibliography}

\section{International Laws and Treaties}

Convention IV Respecting the Laws and Customs of War on Land of 1907.

Geneva Convention IV Relative to the Protection of Civilian Persons in Time 
of War of 1949.

Hague Convention for the Protection of Cultural Property in the Event of Armed Conflict of 1954.

Convention on the Means of Prohibiting and Preventing the Illicit Import, Export, and Transfer of Ownership of Cultural Property o 1970.

UNESCO World Heritage Convention of 1972.

The Second Protocols to the Hague Convention of 1954 for the Protection of Cultural Property in the Event of Armed Conflict 1999.

\section{Books}

Ambarwati, Denny Ramdhany, AND Rina Rusman. Hukum Humaniter Internasional dalam Studi Hubungan Internasional, RajaGrafindo Persada, Jakarta, 2010.

Bokova, Irina. Introduction to Basic Texts for the 1954 Hague Convention for the Protection of Cultural Property in the Event of Armed Conflict and it's two (1954 and 1999) Protocols, UNESCO, 2010.

Delegasi Regional ICRC. Hukum Humaniter Internasional, ICRC, Jakarta, 2015.

Herimanto. Ilmu Sosial \& Budaya Dasar, Bumi Aksara, Jakarta, 2011. International Committee of the Red Cross (ICRC). Discover the ICRC, ICRC, Geneve, 2015, hal. 6.

Kusumaatmadja, Mochtar AND Etty R. Agoes. Pengantar Hukum Internasional, P.T Alumni, Bandung, 2003.

Shaw, Malcolm N. Hukum Internasional, Nusa Media, Bandung, 2013.

\section{Journals, Websites}

Abtahi, Hirad. "The Protection of Cultural Property in Times of Armed Conflict: The Practice of the International Criminal Tribunal for the Former Yugoslavia," Harvard Human Rights Journal, Spring 2000.

Boylan, Patrick J. "Review of the Convetion for the Protection of Cultural Property in the Event of Armed Conflict (The Hague Convention of 1954)," UNESCO Doc, 1993.

Haryomataram, "Konflik Bersenjata dan Hukumnya," Universitas Tri- 
sakti, Jakarta, 2002.

Pictet, Jean S. "Commentary on the Geneva Conventions of 12 August Volume IV: Geneva Convention relative to the Protection of Civilian Persons in Time of War," International Committee of the Red Cross, 1999.

UNESCO, "UNESCO's Response to Protect Culture in Crises, Unite4heritage," 2016.

http: / / unesdoc.unesco.org/images/ 0024 / 002449/244984e.pdf.

http: / / whc.unesco.org/en/list/23.

https: / /whc.unesco.org/en/soc/3217.

https: / /whc.unesco.org/en/soc/3350. 